\title{
CORRECTION
}

View Article Online

View Journal I View Issue

D) Check for updates

Cite this: J. Mater. Chem. A, 2020, 8 , 1485

DOI: $10.1039 / c 9 t a 90300 c$

rsc.li/materials-a

\section{Correction: Cathode materials for lithium-sulfur batteries: a practical perspective}

\author{
Ali Eftekhari ${ }^{\star a}$ and Dong-Won Kim ${ }^{\mathrm{b}}$ \\ Correction for 'Cathode materials for lithium-sulfur batteries: a practical perspective' by Ali Eftekhari et al., \\ J. Mater. Chem. A, 2017, 5, 17734-17776.
}

The Royal Society of Chemistry has been notified by Ulster University that Ali Eftekhari was not authorised to use Ulster University as an affiliation. The affiliation to Ulster University has therefore been removed at the institution's request.

The Royal Society of Chemistry apologises for these errors and any consequent inconvenience to authors and readers. 